\title{
Research on Current Situation and Development Trend of College English Education Reform
}

\author{
Tang Dongdong ${ }^{1, \mathrm{a}}$, Wang Hongxia ${ }^{1, \mathrm{~b}}$ \\ ${ }^{1}$ Qingdao Huanghai University \\ Qingdao, China \\ a707848150@qq.com, bhongxia_2000@sohu.com
}

\begin{abstract}
College English education plays an important role in the college education system. With the continuous development of the times, college English education must be reformed, which is in line with the requirements of Chinese economic, social and cultural development. The current situation and development trend of college English education reform is studied in the paper during the college educational system. English is a very important subject in college education, which plays a positive role in improving students' English basis and practical application ability. A new educational practice is surging in the wave of Chinese educational reform in twenty-first century. The primary task of teachers in teaching is to cultivate students' innovative spirit and practical ability in the process of education, so as to promote the application of innovative teaching theory.
\end{abstract}

Keywords-College English teaching; Reform; Teaching concept; Development trend

\section{INTRODUCTION}

English is one of the most widely used languages all over the world. It has been applied in the world education since many years ago. English is embodied not only in language communication, but also in computer language, scientific terminology and international transportation and daily life. Meanwhile, English is not only the main working language of international exchanges, but also the main language of international science and technology exchange. According to statistics, more than $85 \%$ of the international academic papers are published and read in English, the main academic journals of various disciplines have English version, while the Internet is also mainly used in English [1].

In the information age, English education has great significance to the college students' development in the future. Therefore, college English education not only cultivates students' intercultural communicative competence, but also plays an important role in promoting people's all-round development. During the English education, learning and mastering English is the goal, for the reason acquiring and processing information with great convenience, expanding people's horizons, helping the development of human wisdom, improving cultural literacy and the way of thinking [2]. Nowadays, cultivate the ability of emotional attitude and spirit of cooperation and exchanges of lifelong learning has an irreplaceable role.

\section{THE DEVELOPMENT OF COLLEGE ENGLISH EDUCATION}

\section{A. The past period of English teaching}

College English education has always been attached importance to by Chinese educational circles. The Ministry of Education issued the requirements of College English teaching, which stipulated the nature of College English Teaching: "College English teaching is an organic part of higher education, and College English is a compulsory basic course for college students." College English is a foreign language teaching theory as a guide to English language knowledge and practical skills of learning strategies and intercultural communication as the main content, and a variety of teaching methods and teaching means teaching system. It can be seen that college English education plays an important role in our education system.

Foreign language education in China has gone through a long period of history, which can be traced back to the Qing government advocated a large number of opium wars after the end of the Qing dynasty [3]. Later, due to the massive invasion of imperialism and the successive setback of the Qing government, during the Westernization Movement, the European advanced scientific and cultural knowledge was vigorously studied. The Qing government trained a large number of translation talents, so that English education gradually entered the boom period.

\section{B. Reform exploration and trend}

During the period of the Republic of China, as China was in the period of social transition, the spread of various new trends of thought, such as the 54 Movement and the new culture movement, the climax of learning the science and culture of the European and American countries was aroused by all circles of society. Before the reform and opening up, due to the changes in the national political and economic situation, Chinese foreign language education in colleges is full of twists and turns, and the results are low. After the reform and opening up, China has joined the economic globalization and integration, and foreign language education has a favorable environment for development. Especially in 1977, the college entrance examination resumed, the enrollment of colleges led to the popularization of foreign language education. After the rapid economic development and fierce social competition, in order to better adapt to society, foreign language education gradually toward the younger age, the formation of "English 
Craze" phenomenon. In 80 s, the state issued relevant policies on College English education, such as the CET test. The focus of English education has begun to develop language ability. Since 90s, College English education has added cultural knowledge; nowadays, the reform of College English education has added emotional attitude and learning strategies to English education. The continuous change of English education marks the continuous development and progress of College English education in china

\section{Defects of educational system}

In recent years, College English education tend to utilitarianism, emphasizing English practical and short-term interests. English education has become a long learning time, heavy task, time consuming and inefficient in the subject. "The heat of postgraduate entrance examination" and "overseas hot" under the impetus of the English in a high position, education content mainly revolves a variety of test, examination abroad, CET test is one of the graduate students, training content is all kinds of examination questions, this person may be called a standard of talent, this kind of education has become the "flow education".

In the traditional English teaching, many teachers often neglect the students' interest in learning because of too many teaching tasks. The teaching process into the teachers simply teach, this "cramming education" and "indoctrination" teaching mode, lack of interaction in the teaching of College English education, the atmosphere became low and depressed, the formation of "dumb English".

\section{The goal of English education}

Students are the object of teaching, the recipient of knowledge, the students' psychological state will definitely affect the results of teaching. To have a role in the conversion process, from high school to college without the pressure of the test, without the supervision of teachers and parents, many students lose learning motive, become loose. College English is mostly used as a public course. Students are also qualified to pass the exam. Learning English is only a form.

\section{THE DEVELOPMENT TREND OF COLLEGE ENGLISH EDUCATION REFORM}

\section{A. The resource input structure of English education}

In the examination oriented education system, the results determines the fate of students, which seriously affect the students' ability to adapt to the actual needs of society, so that English cannot play its role as a language tool. It happens in many schools for years.

Due to the different needs of English in all walks of life, college students can adjust their learning goals through the needs of the industry. Students must first pass the relevant information about their future employment direction of the demand for English, have a general understanding of their future employment direction, if their employment direction required strong foreign language level, students will naturally increase the intensity of English learning, so that schools can by students and social demand, adjust and optimize the English Education resource input.

\section{B. Change the traditional way of education}

Language as a tool to disseminate information, we should first pay attention to its application in daily life, learning English is to communicate with people, this is the real purpose of English teaching.

To achieve this goal, it is necessary to change the traditional way of English education. First of all, teachers should accurately understand and grasp the aim of College English education, reading and writing, not only change the phenomenon of the traditional hard of hearing that, around the comprehensive ability to cultivate and improve the students' listening and speaking ability especially in open education, creating English language environment more. Secondly, the role of teaching should be shifted from the traditional teacher centered to student-centered, to cultivate students' enthusiasm and creativity, and to increase the interest and interactivity of the classroom. From the original emphasis on teaching to pay attention to learning, let students study independently, explore actively, and participate in the teaching process, classroom teaching in the democratic, open, interactive atmosphere, together to achieve educational goals. Third, teachers should add emotional factors in teaching, and form a multi-level interaction with students, and actively respond to students' feedback, so that students are more likely to produce trust and favor, and more accept and agree with the teaching of teachers.

\section{The renewal of foreign language teaching concept}

The teaching reform needs to change the traditional teaching mode, improve the students' language output ability, and enhance the pragmatic language application ability, divided into listening, speaking, reading and writing four plates, namely input ability (listening, reading) and output ability (speaking and writing). The lack of output ability in English language is mainly due to the non-English language environment and the traditional teaching methods, which lead to input more than output, that is, the ability of rereading [4].

\section{IMPROVEMENT OF ENGLISH LEARNING CONDITIONS}

In view of the lack of College English class, the heavy task and the lack of students' English language input, it is necessary to actively develop a variety of ways of language input in English education. Teachers should actively participate in, guide and promote the campus "English corner", English radio, English speaking, English competitions and other forms of extra-curricular activities, optimize the campus English learning environment, so that students have more opportunities to practice English, make up for the lack of English classroom. 


\section{A. The conditions for development}

The use of modern teaching methods will help improve the quality of English Teaching in colleges. Therefore, positive measures should be taken to promote the application of these techniques in College English education practice and form a good interactive platform between teachers and students.

College students should adapt themselves to the role requirements as soon as possible, correctly understand the role of English in their future development, realize the role of English as an information communication tool in the future society, and actively learn, not only for the exam oriented education.

\section{B. The development of deductive teaching model}

Deductive teaching model refers to a teaching model based on the assumption of a scientific theory, and then uses rigorous experiments to verify its effectiveness. Inductive teaching model comes from the summary of teaching practice, there are still some uncertainties, and some areas cannot even justify themselves. The deductive teaching model has certain theoretical basis, which avoids the shortage of inductive teaching mode.

The traditional teaching mode emphasizes the main body of education, that is, the role of teachers. Dewey's "antitraditional" teaching mode makes people realize that students should be the main body of learning, thus began to emphasize the study of the main teaching mode. Modern teaching model attaches importance to the subjectivity of students in teaching activities, attaches great importance to students' participation in teaching, and rationally designs the activities of teaching and learning according to the needs of teaching.

\section{Project oriented teaching model}

Project oriented teaching mode is a teaching activity through the implementation of a complete project. Its purpose is to organically combine theory and practice teaching in the classroom teaching, fully explore the students' creative potential, and improve students' comprehensive ability to solve practical problems. In the implementation of "project teaching method", we should pay attention to the selection of the project, the specific achievements display, the evaluation summary of teachers, and make full use of modern teaching and experimental means, which is the key to improve the "project teaching method".

The teacher training to improve the overall quality of teachers for the purpose of taking into account the individual characteristics and needs of teachers, weaken discipline background, enhance practical skills, improve teachers' professional ability and internal potential, and cultivate teachers' team consciousness and sense of responsibility and dedication. The depth and breadth of the theoretical knowledge of teachers in colleges is not to be doubted, but the lack of contact with enterprises leads to the poor ability to transform theoretical knowledge into reality,

"Double teacher type" is the focus and direction of the construction of college teaching staff, and the key to improve the teaching quality of college English education. But at present, there is not a complete train of thought and construction system for the understanding of the connotation of "double-qualified" teachers and the ways and means of construction [5].

\section{THE DEVELOPMENT TREND OF ENGLISH MAJOR CONSTRUCTION}

The trend of multi polarization of professional objectives is characterized by the diversification of professional objectives and the rapid change of professional objectives. The imbalance of regional economic development requires the diversity of talents training objectives, and the adjustment of industrial structure also forces the career goals of college English education to change. Therefore, the multi polarization trend of professional construction is inevitable.

\section{A. Trends in professional connotation}

The renewal trend of professional connotation is manifested as the optimization of professional content and the optimization of curriculum composition. The motivation of the reform of professional connotation comes from the progress of science and technology, on the other hand, from the inherent demand of education. The limited nature of educational resources determines that the maximum benefit of education can be achieved only through the supplement of curriculum content and the optimization of curriculum structure.

The composite trend of professional structure is characterized by the decrease of professional quantity and the widening of professional coverage. Composite trend lead to social adjustment of economic structure and a variety of occupation will inevitably lead to complex professional production, will be fierce tendency of labor market competition caused by change trend similar occupation, it will produce some strong adaptability, wide coverage of wide caliber professional groups.

\section{B. Management mechanism of professional construction}

Due to the diversification of the main body of the school, the balance of interests among all parties becomes an inevitable requirement, which leads to the diversified orientation of the management mechanism of the professional construction of college education.

Under the condition of market economy, the market lever becomes the important basis to adjust the educational demand, the market pays attention to the benefit, the government guarantees the fair, this is a basic principle that the professional construction management should follow. Under this principle, the diversified structure of professional construction management mechanism has emerged under the guidance of the labor market. 


\section{Course content}

Teaching material construction is an important content of curriculum construction, is an important carrier of teaching ideas and teaching content, is the crystallization of teaching methods and experience, is also an important guarantee to improve the quality of teaching, has a wide range of radiation. The development from syllabus to textbooks, teachers should, in the form of school enterprise cooperation of team work, this process is not only a treatment of teaching plan in teaching theory and methodology, and the specific treatment course syllabus in the content level, the curriculum design, it is necessary to carry out the integration of production logic and labor organization of individual companies, but also the integration of the case study and learning system. Therefore, the textbook compiling of college education should follow the principle of combining teaching content with working process, and the design and compilation of the course content should be completed under the joint efforts of full-time teachers and enterprise practitioners.

\section{Course content}

The difference of curriculum development and curriculum design, curriculum design and curriculum content to determine the target selection and other aspects, including curriculum implementation and curriculum evaluation, just to get text level courses and curriculum development, including curriculum text to implement the whole process of student learning.

Only when the college education is committed to the integration of learning in the process of enterprise work and the integration of related learning in the school, the learners can make their professional ability develop through the close combination of the situational work and the background related learning. Therefore, from the cooperation of study places, school enterprise must cooperate to establish training base inside and outside school.

\section{CONCLUSIONS}

The traditional English education has lasted for a hundred years in our country, and the College English education has gone through a long course of development. In China's colleges and universities, English as the second language teaching, due to the lack of communication and cultural environment, as well as the current English education system and teaching methods of defects, resulting in most students do not have more opportunities to practice English. College students learn English with long time and little effect, and their English expression and communication ability is poor. The school should start from the three aspects of the College English education system, teachers and students, redesign the English phonetic learning environment, to achieve more authentic understanding of English cultural exchanges. The government should speed up the reform of College English education, adapting to the needs of rapid economic, social and cultural development, and better serve the social economic and cultural construction of our country.

\section{REFERENCES}

[1] Lou S Q. "On the Infiltration of Aesthetic Education in College English Teaching". Journal of Nanyang Normal University, 2008, pp.81-86.

[2] Kou S W. "On Across-culture Education in College English Teaching". Journal of Qiqihar University, 2006, pp.311-313.

[3] Kang Z Y. "The Goal of College English Education Theory and Puts Forward Some Countermeasures". Career Horizon, 2012, pp.233.

[4] Zong Y. "On Combining Moral Education with College English Teaching". Journal of Dongguan Institute of Technology, 2003,pp.101104.

[5] Tian-Jun F U, Tao S, Wang X Q. "Steering and Breakthrough of College English Education in Information Age". Journal of Shijiazhuang University of Economics, 2016, pp.99-105. 